\title{
Komunikasi antara Jasa Kurir Sepeda dengan Pelanggan (Studi Kasus Kurir Kamiantar Jakarta)
}

\author{
Cayandi Susanto, Gregorius Genep Sukendro \\ cayandisusanto15@gmail.com,geneps@fikom.untar.ac.id
}

Fakultas Ilmu Komunikasi Universitas Tarumanagara

\begin{abstract}
Bicycle courier for now is developing faster than bicycle courier services using motorcycles or cars, because for the use of bicycle transportation is fairly unique and fast in its delivery. The way to order and call a bicycle courier is also faster and it's very easy to just wait from the company to convey if there is an order and immediately accepted by the bicycle courier. The communication process between the bicycle courier service and its customers runs smoothly even though there are 2 customers namely the sender and recipient of the goods or packages. Interpersonal communication is considered very effective to change the behavior of others, if there are similarities about the meaning discussed. The special mark on interpersonal communication lies in the direct reverse flow. The backflow has an easy catch for communicators both verbally in the form of words and non-verbal in the form of body language such as nodding, smiling, frowning and so forth. During the interpersonal communication process it is very important the interaction of sharing information and feelings between individuals and individuals or between individuals so that feedback occurs and does not cause misunderstanding in communication Interpersonal communication plays an important role in communication activities between bicycle courier services with its customers. The aim of the writer to conduct this research is to find out the beginning or the initial stage of communication between the bicycle courier service and 2 customers, namely the sender and recipient of goods and to find out what obstacles / disturbances are when our Jakarta delivery couriers communicate with customers.
\end{abstract}

Keywords: case studies, feedback, interpersonal communication, non-verbal, obstacles, Qualitative

\begin{abstract}
Abstrak
Kurir sepeda untuk saat ini berkembang begitu cepat daripada jasa kurir sepeda yang menggunakan motor atau mobil, dikarenakan untuk penggunaan transportasi sepeda ini terbilang sangatlah unik dan cepat dalam pengirimannya. Cara memesan dan memanggil kurir sepeda pun lebih cepat juga dan mudah sekali tinggal menunggu dari perusahaan itu menyampaikan kalau ada pesanan dan langsung diterima oleh kurir sepeda tersebut. Proses komunikasi antara jasa kurir sepeda dengan pelanggannya berjalan dengan lancar walaupun pelanggan ada 2 yaitu pengirim dan penerima barang atau paket tersebut. Komunikasi antar pribadi dinilai sangat efektif untuk merubah perilaku orang lain, bila terdapat persamaan mengenai makna yang dibincangkan. Tanda khusus yang ada di komunikasi antar pribadi ini terletak pada arus balik langsung. Arus balik tersebut memiliki daya tangkap yang mudah untuk komunikator baik secara verbal dalam bentuk kata maupun non-verbal dalam bentuk bahasa tubuh seperti anggukan, senyuman, mengernyitkan dahi dan lain sebagainya. Selama proses komunikasi antar pribadi berlangsung sangat penting terjadinya interaksi berbagi informasi dan perasaan antara individu dengan individu atau individu dengan antar individu supaya terjadi umpan balik dan tidak menimbulkan kesalahpahaman dalam berkomunikasi Komunikasi antar pribadi berperan penting dalam kegiatan komunikasi antara jasa kurir
\end{abstract}


sepeda dengan pelanggannya. Tujuan penulis melakukan penelitian ini yaitu dikarenakan untuk Untuk mengetahui permulaan atau tahap awal berjalannya komunikasi antara jasa kurir sepeda dengan 2 pelanggan yaitu pengirim dan penerima barang dan untuk mengetahui hambatan/gangguan apa saja saat kurir Kamiantar Jakarta berkomunikasi dengan pelanggan.

Kata Kunci: Komunikasi antar pribadi, Feedback, hambatan, non-verbal, hambatan, Studi Kasus, Kualitatif

\section{Pendahuluan}

Kemacetan di Jakarta yang semakin hari semakin mengkhawatirkan menuntut adanya solusi baru untuk industri jasa antar atau kurir. Sepeda jadi salah satu pilihannya. Walaupun ada kendaraan yang bisa lebih cepat yaitu motor, untuk sekarang ini bisa dilihat kalau kurir sepeda yang bisa lebih cepat daripada jasa kurir motor untuk mengantarkan paket atau barang yang ingin dikirimkan. Dengan mudah sepeda bisa melewati jalan sempit dan jalan yang susah dilewati oleh kendaraan bermotor, maka dari itu jasa kurir sepeda yang untuk saat ini banyak yang lebih berminat daripada menggunakan motor dikarenakan juga untuk jasa kurir sepeda ini terbilang unik dan memang baru untuk di Jakarta ini (https://finance.detik.com/berita-ekonomi-bisnis/d4674697/sulap-sepeda-jadi-peluang-bisnis-kurir-antimacet?_ga=2.220785816.1007235272.1579048986-823203122.1576172689).

Setiap hari berada di jalanan adalah pekerjaan dari para kurir sepeda atau bike messenger. Mengirimkan barang yang dipercayakan kepada customer dengan tepat waktu menggunakan sepeda. Terbayang begitu beratnya pekerjaan mereka yang harus berbagi jalan dengan pengguna jalan lainnya. Tak jarang mereka harus bertemu dengan pengguna jalan lain yang tidak memerhatikan keberadaan mereka (https://health.detik.com/kebugaran/d-3942993/berbagi-jalan-dengan-kendaraanbermotor-ini-harapan-para-kurirsepeda?.ga=2.154239032.1007235272.1579048986-823203122.1576172689).

Komunitas sepeda yang sangat diminati untuk sekarang ini adalah sepeda fixie, Sepeda fixie merupakan nama jenis sepeda yang berasal dari Amerika Serikat, tepatnya di kota New York, Sepeda fixie atau fixed gear digunakan oleh pengantar pos/surat kabar/majalah, Karena kondisi kota New York sangat padat, mereka sering terlambat ketika mengantar paket mereka. Akhirnya mereka memilih sepeda fixed gear sebagai alternatif dan hasilnya sangat memuaskan karena pengiriman yang lebih cepat (http://www.neraca.co.id/article/15072/fenomena-sepeda-fixie-peluang-bisnis-darisudut-kota-new-york).

Penggunaan sepeda namun bukan hanya bisa untuk mengantar barang atau sebagai kurir sepeda, tetapi juga umumnya digunakan untuk pergi ke sekolah, kampus, atau ke kantor. Sisi positif selain karena ikut tren, bersepeda tentu dapat mempermudah dan mempercepat pengiriman barang atau paket, dan penggunaan sepeda juga dapat memperlambat pemanasan Global yang baru-baru ini menjadi pembahasan media karena banyak sekali lingkungan yang kalau bisa dibilang sangat banyak sekali yang tercemar

(https://www.kompasiana.com/hendyprabowo/550035dba333114e7550ff18/sepedauntuk-mengurangi-pemanasan-global).

Kurir sepeda adalah jasa kurir umumnya namun yang menarik adalah dengan transportasinya memakai sepeda, tentu untuk di Jakarta sendiri sangatlah jarang dan unik, dikarenakan biasanya masyarakat yang ingin mengirim pesan tentu 
Cayandi Susanto, Gregorius Genep Sukendro: Komunikasi antara Jasa Kurir Sepeda dengan Pelanggan (Studi Kasus Kurir Kamiantar Jakarta)

menggunakan jasa kurir yang menggunakan motor atau mobil, namun yang terjadi sekarang banyak sekali masyarakat yang mencoba untuk mengirim barang menggunakan jasa kurir sepeda tersebut (https://www.boombastis.com/kurirsepeda/71259).

Tujuan penelitian ini adalah tujuan penulis melakukan penelitian ini yaitu dikarenakan untuk Untuk mengetahui permulaan atau tahap awal berjalannya komunikasi antara jasa kurir sepeda dengan 2 pelanggan yaitu pengirim dan penerima barang dan untuk mengetahui hambatan/gangguan apa saja saat kurir Kamiantar Jakarta berkomunikasi dengan pelanggan.

\section{Metode Penelitian}

Peneliti akan menggunakan dokumentasi dan rekaman arsip. Narasumber yang menjadi subjek dari penelitian ini dianggap sebagai key informan dan mengetahui informasi mengenai objek dalam penelitian.

Narasumber yang penulis wawancarai dalam penelitian ini berjumlah 3 orang, yaitu $C E O$ dari Kamiantar Jakarta, Kurir sepeda Kamiantar Jakarta, Pelanggan Jasa kurir Kamiantar Jakarta. Dari hasil wawancara banyak sekali jawaban-jawaban yang membantu penulis dalam meneliti komunikasi antara jasa kurir dengan pelanggannya.

Penulis juga mengutip dari jurnal pembimbing penulis yaitu Bapak Gregorius Genep Sukendro, Dosen Universitas Tarumanagara, yang berjudul Diagnosa Komunikasi Brand Activation Dan Media Digital Atas Eksistensi Brand Studio Rekaman Lokananta. Pemanfaatan media komunikasi berbasis digital dan brand activation oleh industri dapat menarik perhatian calon konsumen atau pelanggan. Bahkan dari kedua kegiatan ini kepercayaan dan loyalitas konsumen kepada brand dapat dicapai. Penelitian ini akan melihat bagaimana brand activation dan komunikasi berbasis digital berhasil dapat menarik perhatian konsumen.

Oleh karena itu sejumlah teori komunikasi akan digunakan dalam penelitian ini untuk membedah dan memotret objek penelitian. Tentu ini sama dengan penelitian yang dilakukan oleh penulis, dikarenakan penulis membahas juga dari pemanfaatan media komunikasi berbasis digital yang bisa dibilang yaitu Media sosial, dimana penulis bisa berkomunikasi dengan siapapun melalui media sosial Instagram atau Whatsapp, komunikasinya pun secara tidak langsung karena menggunakan media komunikasi digital. Jadi alasan penulis mengambil tentang jurnal dari Pak Gregorius Genep Sukendro dikarenakan ada bagian-bagian yang menurut penulis bisa diambil untuk dijadikan kunci untuk penelitian ini.

Dalam penelitian ini peneliti menggunakan metodologi penelitian kualitatif dengan pendekatan metode studi kasus (case study). Menurut (Bimo Walgito, 2010) studi kasus adalah metode yang bertujuan untuk mempelajari dan menyelidiki suatu kejadian atau fenomena mengenai individu atau kelompok dan juga dibutuhkan banyak informasi dan integrasi data guna mendalami penelitian.

Menurut (Susilo Rahardjo \& Gudnanto, 2011) Masih dalam ranah bimbingan dan perkembangan diri, Susilo Rahardjo \& Gudnanto menyatakan bahwa studi kasus merupakan metode yang diterapkan untuk memahami individu lebih mendalam dengan dipraktekkan secara integratif dan komprehensif. Hal ini dilakukan supaya peneliti bisa mengumpulkan dan mendapatkan pemahaman yang mendalam mengenai individu yang diteliti, berikut masalah yang dihadapi supaya dapat terselesaikan dan membuat diri individu tersebut berkembang lebih baik. 
Berdasarkan pengertian diatas, maka dapat dikemukakan bahwa studi kasus adalah metode yang berupaya untuk mengetahui dan mendalami suatu fenomena dengan mengumpulkan informasi dan data-data. Dalam penelitian ini penulis menggunakan studi kasus untuk menggali dan mengetahui secara mendalam bagaimana komunitas sepeda fixie dan jasa kurir sepeda fixie Kamiantar Jakarta.

Objek dalam penelitian ini adalah cara komunikasi mereka antara jasa kurir sepeda fixie dengan pelanggannya yang sampai saat ini masih konsisten menggunakan sepeda fixie dalam kesehariannya mengantar barang dari pelanggan pengirim ke pelanggan penerima barang tersebut, tidak terpengaruh oleh kemajuan industri otomotif dan transportasi. Penulis akan melakukan wawancara secara langsung kepada narasumber untuk mendapatkan jawaban dari rumusan masalah dalam penelitian dan untuk melengkapi data-data yang terkait dengan proses penelitian sehingga penelitian ini mendapatkan hasil yang baik.

\section{Hasil Penemuan dan Diskusi.}

Metode pengumpulan data kualitatif pada penelitian ini wawancara mendalam yang dimana peneliti mewawancarai seorang CEO Kamiantar Jakarta, Peneliti mewawancarai kurir sepeda Kamiantar Jakarta, dan Peneliti mewawancarai Pelanggan dari Jasa kurir Kamiantar Jakarta. wawancara CEO Kamiantar Jakarta secara online dikarenakan Mas Niki tidak bisa membagikan waktunya karena padat jadwal yang Mas Niki kerjakan sehingga wawancara dilakukan melalui chat WhatsApp. Kalau kurir sepeda dan pelanggan Kamiantar Jakarta, penulis melakukan wawancara di rumah dari pelanggan Kamiantar Jakarta dikarenakan penulis sudah janjian dengan kurir sepeda kalau penulis ingin melakukan wawancara, dan pada akhirnya penulis berkunjung dan melakukan wawancara dengan kurir sepeda dan pelanggan di rumah pelanggan di daerah Kemang.

Hasil penemuan yang penulis dapatkan adalah banyak sekali cara Kurir sepeda Kamiantar Jakarta berkomunikasi dengan pelanggannya walaupun lewat secara tidak langsung dan secara langsung, dikarenakan sebelum bertemu secara langsung kurir sepeda berkomunikasi secara tidak langsung dikarenakan masih berkomunikasi lewat media sosial yaitu Instagram atau Whatsapp dan ketika kurir sepeda bertemu dengan Pelanggan makan itulah komunikasi secara langsung. Memang kurir sepeda itu bertemu dengan 2 pelanggan yaitu pengirim dan penerima dari jasa kurir sepeda Kamiantar Jakarta ini.

Hasil selanjutnya adalah penulis bisa mengetahui kalau komunikasi yang berjalan antara kurir sepeda dengan pelanggan yaitu masih menimbulkan gangguan/hambatan sehingga mengganggu komunikasi antara kurir sepeda dengan pelanggan, contohnya ketika kurir sepeda berkomunikasi secara online, tentu hambatan yang sering terjadi adalah Gangguan lingkungan seperti sinyal dan internet, kalau tidak ada internet tentu komunikasi sedikit mengalami hambatan dan terjadinya gangguan saat berkomunikasi, penulis pun mengetahui apa saja hambatan yang terjadi saat berkomunikasi.

Diskusi yang penulis lakukan kepada kurir sepeda adalah sedikit ingin mendalami seberapa lelahnya menjadi seorang kurir sepeda, mendapatkan pendapatan cukup atau tidak, dan berapa lama bekerja sebagai kurir sepeda untuk sampai saat ini, itulah diskusi dari penulis dengan kurir sepeda Kamiantar Jakarta.

Pada saat wawancara peneliti menemukan tahapan-tahapan proses yang dilakukan oleh Kamiantar Jakarta 
Cayandi Susanto, Gregorius Genep Sukendro: Komunikasi antara Jasa Kurir Sepeda dengan Pelanggan (Studi Kasus Kurir Kamiantar Jakarta)

Gambar 1. Proses Pemesanan dan Pengiriman Jasa kurir Kamiantar Jakarta Proses 1 : Pemesanan

pelanggan melakukan pemesanan jasa Kamiantar Jakarta
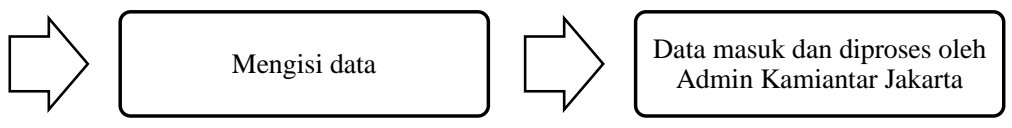

Proses 2 : Penerimaan

data masuk dan diproses oleh Admin Kamiantar Jakarta
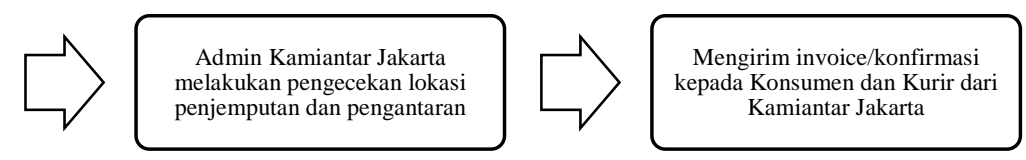

Proses 3 : Pembayaran
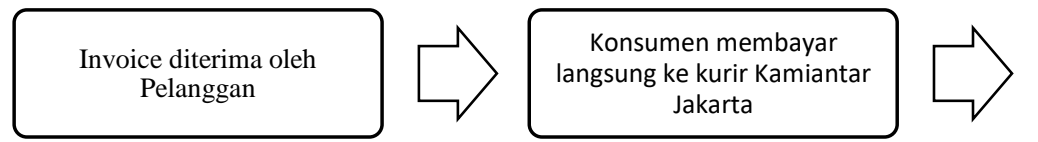

pembayaran selesai Barang dibawa untuk diantarkan ke tujuan

Proses 4 : Pengiriman

Pembayaran diterima oleh Kurir

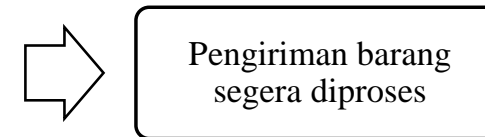

Sumber: Dokumentasi Peneliti (2019)
Barang diterima oleh penerima barang

Pengiriman barang merupakan suatu proses dimana setelah berbelanja atau memang ingin mengirim barang ke suatu tujuan yang biasanya dilakukan oleh masyarakat. Namun perbedaan dari pengiriman barang lainnya dikarenakan dikirim dengan menggunakan sepeda fixie dan pemesanan jasa kurir tersebut harus melalui online dengan Instagram atau chatting WhatsApp.

Proses-proses pemesanan Kamiantar :

1. Pemesanan :

Pelanggan menghubungi Kamiantar Jakarta melalui Direct Message Instagram atau via Chat WhatsApp,lalu menunggu balasan dari Admin Kamiantar Jakarta, masukan nama pengirim, penerima, alamat pengirim, alamat penerima, dan jenis barang yang ingin diantar. Menunggu kembali proses dari admin Kamiantar Jakarta.

2. Penerimaan :

Admin sudah menerima pesanan kurir, lalu memberikan harga tarif yang harus dibayarkan, admin memberi info kepada kurir penjemputan barang dan pengiriman barang,lalu kurir akan segera datang menjemput barang yang ingin diantar

3. Pembayaran :

Kurir datang memberikan invoice tarif, konsumen langsung membayar biaya yang harus dibayarkan sesuai tarif yang sudah ditentukan. Setelah pembayaran selesai lalu barang tentu diambil dan akan dibawa oleh kurir Kamiantar. 
4. Pengiriman :

Pengiriman barang langsung diproses pengantaran sesuai tujuan yang tertera, lalu barang tentu akan sampai ke tempat tujuan dengan aman dan cepat.

\section{Simpulan}

Berdasarkan penelitian yang telah dilakukan oleh penulis untuk mengetahui bagaimana komunikasi antar jasa kurir sepeda dengan pelanggan (studi kurir sepeda Kamiantar Jakarta), kesimpulan yang dapat diambil oleh penelitian ini sebagai berikut yaitu bahwa komunikasi yang sangat berperan sekali untuk suatu permulaan dari jasa dengan pelanggan,ketika harus bertemu dengan pelanggan tentu harus mampu mendapatkan feedback yang positif dari pelanggan.

Komunitas berpengaruh sangat besar terhadap perkembangan kreativitas pengguna sepeda fixie di Jakarta karena di komunitas itu mereka dapat melakukan berbagai macam hal positif. Dengan adanya komunitas sepeda ini dapat menimbulkan suatu titik usaha yaitu untuk sekarang ini ada kurir mengantar barang dan dokumen dengan menggunakan sepeda tentu menghasilkan nilai positif dan bisa juga sebagai hobi, serta komunitas juga berperan penting bagi para pecinta sepeda fixie karena sangat menimbulkan hal positif dan cinta akan komunitas yang kuat atau solid. Teori yang digunakan yaitu teori Komunitas.

Social media sangat berpengaruh terhadap penggunaan jasa kurir sepeda di Jakarta untuk mengantar barang atau dokumen, karena menggunakan social media seperti Instagram dan WhatsApp, karena kalau Instagram itu bisa dibilang dapat mengantarkan informasi yang begitu cepat sesuai keinginan dari masyarakat. Bisa melihat informasi dengan gambar yang jelas dan membuat mudah masyarakat menggunakannya. Teori yang digunakan yaitu teori New Media.

Komunikasi tentu tidak mudah ketika penulis bertemu dengan orang yang tidak kenal maka dari itu harus mendalami bagaimana penulis memulai komunikasi dengan kurir sepeda saat ingin wawancara dan juga dengan pelanggan dari Kamiantar Jakarta, dan ketika kita berkomunikasi tentu menimbulkan beberapa gangguan/hambatan dari komunikasi secara langsung maupun secara tidak langsung. Kalau secara langsung biasanya itu terdapat gangguan suara disaat kita sedang berkomunikasi ada saja suarasuara yang mengganggu jalannya komunikasi, kalau secara tidak langsung terdapat gangguan lingkungan dikarenakan bisa saja gangguan dikarenakan koneksi internet atau sinyal karena komunikasi secara tidak langsung biasanya komunikasi dengan menggunakan komunikasi digital/elektronik.

\section{Ucapan Terima Kasih.}

Penulis mengucapkan rasa syukur dan terima kasih atas penyelesaian penelitian ini kepada Fakultas Ilmu Komunikasi Universitas Tarumanagara dan para narasumber dan responden yang sudah menjadi populasi dalam penelitian ini, dan sudah bersedia meluangkan waktu untuk turut membantu penulis dalam menyelesaikan penelitian ini dengan singkat, jelas, dan padat sehingga membantu penulis dalam menyelesaikan penelitian ini dengan mudah. 
Cayandi Susanto, Gregorius Genep Sukendro: Komunikasi antara Jasa Kurir Sepeda dengan Pelanggan (Studi Kasus Kurir Kamiantar Jakarta)

\section{Daftar Pustaka.}

Dames. (2019, Desember 8). Wawancara pribadi. Jakarta.

Dewantara, Almas. (2019, Desember 8). Wawancara pribadi. Jakarta.

Nazir, Moh. (2011). Metode Penelitian. Bogor: Ghalia Indonesia.

Rahardjo, Susilo \& Gudnanto.(2011). Pemahaman Individu Teknik Non Tes. Kudus: Nora Media Enterprise

Rakhmat, Jalaluddin. (2007). Metode Penelitian Komunikasi. Bandung: PT.Remaja Rosdakarya.

Rizky, Niki Bagoes. (2019, Desember 8). Wawancara pribadi. Jakarta.

Sukendro, Gregorius Genep., \& Pandrianto, Nigar. (2018). Diagnosa Komunikasi Brand Activation Dan Media Digital Atas Eksistensi Brand Studio Rekaman Lokananta. $\quad 10.24912 /$ jk.v11i1.4287 (2018). Terarsip: https://journal.untar.ac.id/index.php/komunikasi/article/view/4287

Robert, K. Yin. (2013). “Studi Kasus”(Desain dan Metode), Jakarta : PT Raja Grafindo.

Walgito, Bimo. (2010). Bimbingan dan Konseling Studi \& Karir. Yogyakarta: Andi 